\title{
Effect of N-acetylcystein on ERK Gene Expression in Ovarian Tissue of Acrylamide-Treated Adult Rats
}

\author{
Naimi $\mathbf{M}^{1,2}$, Shariati $\mathrm{M}^{3}$, Naeimi $\mathrm{S}^{4}$, Edalatmanesh $\mathrm{MA}^{2}$ \\ ${ }^{I}$ Department of Biology, Fars Science and Research Branch, Islamic Azad University, Fars, Iran \\ ${ }^{2}$ Department of Biology, Shiraz Branch, Islamic Azad University, Shiraz, Iran \\ ${ }^{3}$ Department of Biology, Kazerun Branch, Islamic Azad University, Kazerun, Iran \\ ${ }^{4}$ Department of Genetics, Kazerun Branch, Islamic Azad University, Kazerun, Iran \\ E-mail:mehrdadshariati@kau.ac.ir
}

(received 17-12-2019; revised 13-02-2020; accepted 14-02-2020)

\begin{abstract}
ABSTRAK
Naimi M, Shariati M, Naeimi S, Edalatmanesh MA. 2020. Pengaruh N-acetylcystein terhadap ekspresi gen ERK pada jaringan ovarium tikus dewasa yang mendapat perlakuan akrilamida. JITV 25(1): 11-18. DOI: http://dx.doi.org/10.14334/jitv.v25i1.2161.

Akrilamida (AA) merupakan komponen karsinogenik yang diproduksi selama proses memasak. Penelitian ini bertujuan untuk melihat pengaruh $\mathrm{N}$-asetilsisten (NAC) terhadap ekspresi gen kinase pengatur sinyal ektraseluler (ERK) pada perubahan histopatologi ovarium tikus yang mendapat perlakuan akrilamida (AA). Sebanyak 36 tikus betina Wistar dewasa dikelompokkan secara acak ke dalam 6 kelompok yaitu kontrol, kontrol positif (+VE Con), kontrol negatif (-VE Con), eksperimental 1 (Exp1), eksperimental 2 (Exp2) and eksperimental 3 (Exp3). Dua puluh delapan hari setelah perlakuan, tingkat ekspresi gen ERK diukur menggunakan metode PCR real-time dan kemudian dilakukan pemeriksaan terhadap perubahan histopatologi ovariumnya. Tingkat ekspresi gen ERK menurun secara signifikan pada kelompok +VE Con, Exp1 dan Exp2 dibandingkan dengan kontrol $(\mathrm{p}<0,05)$ tetapi tidak pada kelompok -VE Con dan Exp3 $(\mathrm{p}>0,05)$. Secara histologi, kelompok +VE Con menunjukkan penurunan jumlah yang signifikan pada folikel primer, sekunder dan Graafian juga korpus luteum dibandingkan dengan kelompok kontrol $(\mathrm{p}<0,05)$ tetapi berbeda pada kelompok negatif, Exp2 dan Exp3 $(\mathrm{p}>0,05)$. Pada kelompok Exp1, jumlah folikel primer dan sekunder juga korpus luteum menurun secara signifikan $(\mathrm{p}<0,05)$ tetapi jumlah folikel Graafian dan korpus luteum meningkat secara signifikan dibandingkan dengan kelompok $+\mathrm{VE}$ Con $(\mathrm{p}<0,05)$. AA dapat meningkatkan apoptosis dan degradasi folikulogenesis jaringan ovarium dengan menurunkan ekspresi gen ERK. Pemberian NAC memperbaiki pengaruh buruk AA dalam dosis ketergantungan dan meningkatkan folikulogenesis dengan menurunkan tingkat apoptosis. Oleh karena itu, suplementasi NAC dapat memperbaiki tingkat kesuburan hewan.
\end{abstract}

Kata Kunci: Akrilamida, Apoptosis, ERK, Tikus Betina, N-asetilsisten

\section{ABSTRACT}

Naimi M, Shariati M, Naeimi S, Edalatmanesh MA. 2020. Effect of $\mathrm{N}$-acetylcystein on ERK gene expression in ovarian tissue of acrylamide-treated adult rats. JITV 25(1): 11-18. DOI: http://dx.doi.org/10.14334/jitv.v25i1.2161.

Acrylamide (AA) is a toxic and carcinogenic compound produced in cooking process. The purpose of this study is to evaluate the effect of $\mathrm{N}$-acetylcysteine (NAC) on extracellular signal-regulated kinase (ERK) gene expression level and ovarian histopathological changes in AA-treated rats. Thirty-six female adult Wistar rats were randomly divided into 6 groups including control, positive control (+VE Con), negative control (-VE Con), experimental 1 (Exp1), experimental 2 (Exp2) and experimental 3 (Exp3). Twenty eight days after the treatment, ERK gene expression level was measured by real-time PCR method and ovarian histopathological changes were evaluated. The ERK gene expression level was significantly decreased in the $+\mathrm{VE}$ Con, Exp1 and Exp2 groups as compared to the control group $(\mathrm{p}<0.05)$, but not in the -VE Con and Exp3 groups ( $>0.05$ ). Histologically, the $+\mathrm{VE}$ Con group showed a significant decrease in the number of primary, secondary and Graafian follicles as well as corpus luteum as compared to the control group $(p<0.05)$, but not in the negative, Exp2 and Exp3 groups ( $p>0.05)$. In the Exp1 group, the number of primary and secondary follicles as well as corpus luteum significantly decreased ( $\mathrm{p}<0.05)$, however, the numbers of Graafian follicle and the corpus luteum were significantly increased as compared to the +VE Con group $(\mathrm{p}<0.05)$. The AA was supposed to increase the apoptosis and folliculogenesis degradation in the rat ovarian tissue by decreasing ERK gene expression. Administration of NAC ameliorated the deleterious effects of AA in a dose-dependent manner and improve folliculogenesis by reducing apoptosis level. Thus, the NAC supplement could be helpful in ameliorating animal fertility.

Key Words: Acrylamide, Apoptosis, ERK, Female Rat, N-acetylcysteine 


\section{INTRODUCTION}

Nowadays, with the change in lifestyles and diets, manufacturers are increasingly focused on fried foods, so that heating food at high temperatures is a common way of producing processed foods. Although heat processes are one of the most important ways for preserving foods that improve some food properties, it seems that these processes are capable of forming a wide range of toxic compounds such as acrylamide (AA) (Proietti et al. 2014). The AA has a chemical formula $\mathrm{C}_{3} \mathrm{H}_{5} \mathrm{NO}$ is a low-molecular-weight, colorless and odorless compound that is produced in foods containing starch (high amount) and protein (low amount) during cooking process at high temperatures (> $120{ }^{\circ} \mathrm{C}$ ) and it is also widely used in industries and laboratories (Kahkeshani et al. 2014). Studies showed that $\mathrm{AA}$ is tumorigenic and carcinogenic in different human tissues (Klaunig 2008). Acrylamide is rapidly absorbed through the gastrointestinal tract and metabolized to glycidamide (GA) via cytochrome P450 2E1 monooxygenase, which is much more reactive than AA (Aydin 2018). Various studies confirmed the toxic effects of AA and its metabolite, GA, on neurons and the reproductive system as well as the carcinogenic effects on various tissues of the body such as the liver, kidney, intestine, and lung (Kahkeshani et al. 2014). Acrylamide can induce oxidative stress and reactive oxygen species by decreasing the capacity of the antioxidant system, thereby reducing glutathione levels and increasing lipids peroxidation (Zhang et al. 2011a). Active oxygen species play a key role in important biological processes such as cell apoptosis, meiosis restart, and aging. Increased levels of reactive oxygen species are associated with decreased intracellular oxidation-regeneration reactions, thereby increasing apoptosis (Duan et al. 2015). Although apoptosis is essential for the development and normal function of the ovary and testis, it has been found that AA can affect the reproductive system of both sexes by altering the expression of genes responsible for apoptosis (Duan et al. 2015; Camacho et al. 2012). The extracellular signal-regulated kinase (ERK) is a member of the mitogen-activating protein kinases family that controls a wide range of cellular activities such as proliferation, migration, differentiation, and death. Proper ERK activity induces the survival and inhibition of cell apoptosis and its overexpression causes cancer, but under certain conditions can also have a pro-apoptotic function (Cagnol \& Chambard 2010; Sumizawa \& Igisu 2007).

$\mathrm{N}$-acetylcysteine (NAC), which is considered as a cheap and safe antioxidant and drug, is a potent source of sulfhydryl groups that converts to metabolites that stimulate glutathione production and directly removes free radicals (Mokhtari et al. 2017). The NAC has been used as a mucolytic drug in respiratory diseases for many years but has also been useful in the treatment of other diseases including cancer, heart diseases, heavy metal poisoning, influenza prevention, epilepsy and acetaminophen poisoning (Saha et al. 2013). Studies have shown that NAC can reduce the production of some cytokines such as alpha tumor necrosis factor (TNF- $\alpha$ ) and interleukin-6 (IL-6) and thus modulates pro-inflammatory pathways (Al-Shukaili et al. 2009). It has also been shown that NAC can inhibit apoptosis by decreasing oxidative stress and enhancing cell survival (Daneshpoya et al. 2017). Due to various pharmacological effects of NAC and its relative safety, the tendency to use it has increased in recent years (Demedts et al. 2005). This drug has an important functional spectrum in the body, such that it increases the cellular levels of reductive glutathione as a potent antioxidant system and on the other hand, improves the function and regulation of intracellular redox systems (Mokhtari et al. 2017; Markoutsa \& Xu 2017). Also, immunological functions have been proposed (Arranz et al. 2008). Since ovarian tissue damage can lead to subfertility or infertility, and since AA can damage the reproductive system, especially ovarian tissue and considering that there has been limited research in this field, therefore, in the present study, the protective effect NAC on the ovarian tissue apoptosis was studied by measuring the expression level of ERK gene as well as the rate of morphometric and histopathological changes of ovarian tissue in AA-treated rats.

\section{MATERIALS AND METHODS}

\section{Animals}

Adult female Wistar rats weighing $220 \pm 20 \mathrm{~g}$ were obtained from the animals' house of Islamic Azad University of Kazerun and were adapted to the new environmental conditions for 2 weeks. They were kept at standard conditions at $22 \pm 2{ }^{\circ} \mathrm{C}, 12$ hours of darkness/daylight and $70 \%$ humidity. During the study, the animals had access to food and water ad libitum. The protocol of this study was approved by the Ethics Committee of Islamic Azad University of Kazerun, Iran, in relation to working with laboratory animal care (Ethical code no: IR.IAU.SHIRAZ.16330525651006).

\section{The experiment protocol}

The rats were randomly divided into 6 groups of 6 rats i.e. control, positive control (+VE Con), negative control (-VE Con), experimental 1 (Exp1), experimental 2 (Exp2) and experimental 3 (Exp3). The control group received no special treatment. Animals in the +VE Con 
group received $50 \mathrm{mg} / \mathrm{kg}$ AA (Merck, Germany) orally. The animals in the -VE Con group received $40 \mathrm{mg} / \mathrm{kg}$ NAC (Merck, Germany) intraperitoneally. The animals in the Exp1, Exp2, and Exp3 groups received 10, 20 and $40 \mathrm{mg} / \mathrm{kg}$ NAC at 9 am intraperitoneally and 50 $\mathrm{mg} / \mathrm{kg}$ AA at $5 \mathrm{pm}$ orally. The study duration was 28 days and similar in all groups. The dose of AA and NAC was selected based on previous studies (Camacho et al. 2012; Chiew et al. 2016). At the end of the study, the animals were anesthetized using ether and the left and right ovaries of each animal were removed for histological examination.

Prior to the study, the rats co-cycling was performed to place them in a phase of the estrous cycle as the following. At first, $100 \mu \mathrm{g}$ Estradiol valerate (Aburaihan, Iran) was dissolved in $0.2 \mathrm{ml}$ olive oil and injected intramuscularly with an insulin syringe. After 42 hours, $50 \mu \mathrm{g}$ progesterone (Aburaihan, Iran) was injected intramuscularly and 6 hours later, the vaginal smear was collected. Each stage of the estrous cycle was diagnosed based on the ratio between three types of cell populations (epithelial cells, keratinized cells, and leukocytes) observed in vaginal smears (Marcondes et al. 2002). Microscopic observations were made in rats that their estrous phase had been synchronized.

\section{Quantitative analysis of ERK gene expression using real-time PCR}

To extract RNA, a small piece of ovarian tissue was removed and washed twice with phosphate buffer saline. Then, the samples were evaporated and powdered in liquid nitrogen for 1 minute. Trizol $(1 \mathrm{ml})$ (GeneAll Biotechnology, South Korea) was added to the resulting powder in a micro-tube and homogenized with a manual homogenizer for two minutes on the ice. The samples were incubated at room temperature for 5 minutes and then $200 \mu \mathrm{l}$ chloroform was added for fat removal and shaken for 15 seconds. The resulting milky mixture was centrifuged at $12000 \mathrm{RCF}$ for 15 minutes at $4{ }^{\circ} \mathrm{C}$. Then, the supernatant-containing RNA was transferred into a sterile micro-tube.

A volume of buffer RB1 (GeneAll Biotechnology, South Korea) was added to the micro-tube-containing supernatant and then the micro-tube contents were transferred to the column. After 30 seconds of centrifugation at room temperature at $12000 \mathrm{RCF}$, the infranatant was removed and $500 \mu \mathrm{l}$ of buffer SW1 (GeneAll Biotechnology, South Korea) was added. After 30 seconds centrifugation at the room temperature and $12000 \mathrm{RCF}$, the infranatant was removed again. Next, $500 \mu \mathrm{L}$ of buffer RNW (GeneAll Biotechnology, South Korea) was added to the column, and after centrifugation at the room temperature and $12000 \mathrm{RCF}$, the columns were transferred to a new micro-tube and $50 \mu \mathrm{L}$ of nuclease-free water was added and RNA was purified after centrifugation at $12000 \mathrm{RCF}$.

Using reverse transcription reaction (RT-PCR), mRNA conversion to cDNA was performed using the manufacturer's instructions (Biofact, South Korea). To investigate the quality of cDNA, the polymerase chain reaction with specific primer (Metabion, Germany; FCGTGCGTGACATTAAAGAGAA and RCGCTCATTGCCGATAGTGAT) for $\beta$-Actin gene as a housekeeping gene was examined. Then, in order to amplify the target fragment and quantify the expression of the ERK gene, Real-time PCR reaction was performed by a cyber green method using Qiagenmanufactured Q rotor Gene.

RT-PCR reaction using specific primers (Metabion, Germany; F- CGTTCAGATGTCGGTGTC and RAAAGGAGTCAAGAGTGGG), ERK gene (Wang et al. 2015) and the reaction mixture of Power SYBR green PCR master mix (Applied Biosystems, UK) was performed during a program at $95^{\circ} \mathrm{C}$ for 10 minutes, 40 cycles at $95^{\circ} \mathrm{C}$ for 15 seconds and at $60^{\circ} \mathrm{C}$ for 1 minute. The mean of CTs was calculated using $2^{-\Delta \mathrm{CT}}$.

\section{Histopathological analysis of ovarian tissue}

After removing the left and right ovaries of all animals, the adipose tissue around them was removed and fixed in $10 \%$ buffered formalin. After tissue processing, the tissue samples were blocked in paraffin and then 5-micron thick serial sections were provided longitudinally and centrally using a microtome machine. The sectioned were stained with hematoxylin-eosin and then the number of primaries, secondary, Graafian follicles as well as corpus luteum was counted under light microscopy. The follicles were counted spirally from a point at the cortex clockwise toward the medulla.

\section{Statistical analysis}

SPSS software version 20 was used for data statistical analysis. At first, the normality of the data was confirmed using Kolmogorov-Smirnov test, and then by using one-way ANOVA and LSD post hoc tests, data analysis was performed at $\mathrm{P}<0.05$. The results were expressed as mean \pm standard deviation in the table and graph. The GraphPad Prism version 6 software (GraphPad Prism, Inc., San Diego, CA, USA) was also used to design ERK gene expression graph. 


\section{RESULTS AND DISCUSSION}

\section{Result}

\section{ERK gene expression}

The results of ERK gene expression in different groups (Figure 1) showed that in the +VE Con group, the level of ERK gene expression had significantly decreased as compared to the control group $(p<0.05)$, but no significant differences between the -VE Con and the control groups were observed $(\mathrm{p}>0.05)$. The gene expression level in the Exp1 and Exp2 groups were significantly decreased as compared to the control group $(\mathrm{p}<0.05)$, but in the Exp2 group, there was a significant increase in ERK gene expression level as compared to the $+\mathrm{VE}$ Con group $(\mathrm{p}<0.05)$. The Exp3 group had a significant increase compared to the $+\mathrm{VE}$ Con group $(p<0.05)$, while there wasn't a significant difference with the control group ( $p>0.05)$.

\section{Morphometric and histopathological findings of the ovarian tissue}

Histopathological examination of the ovarian tissue in different groups (Table 1) showed that in the +VE Con group, the number of primaries, secondary and Graafian follicles as well as corpus luteum had significantly decreased as compared to the control group $(p<0.05)$, while in the -VE Con group, no significant differences were found with the control group $(\mathrm{p}>0.05)$. In the Exp1 group, the number of primary and secondary follicles and corpus luteum decreased significantly $(\mathrm{p}<0.05)$. Also, the number of Graafian follicles and corpus luteum in the Exp1 group significantly increased compared to $+\mathrm{VE}$ Con group $(\mathrm{p}<0.05)$. There was no significant difference in the number of Graafian follicles in the Exp1 group $(p>0.05)$. In the Exp2 and Exp3 groups, the number of primaries, secondary, Graafian follicles as well as corpus luteum increased significantly $(\mathrm{p}<0.05)$ compared to the +VE Con group ( $\mathrm{p}>0.05)$, while there was no significant difference with the control group $(\mathrm{p}>0.05)$.

Morphometrically results in the ovarian tissue sections indicated that normal folliculogenesis did take place in the control, -VE Con, Exp2 and Exp3 groups and different follicles including Graafian follicles with a thick layer of granulosa cells and corpus luteum were present. In the +VE Con and Exp1 group, folliculogenesis had been largely destroyed and a small number of corpus luteum was observed indicating a decrease in ovulation (Figure 2).

\section{Discussion}

In this study, the effect of AA $(50 \mathrm{mg} / \mathrm{kg})$ and NAC $(10,20$ and $40 \mathrm{mg} / \mathrm{kg})$ on ERK gene expression levels, as well as morphometric and histopathological changes in the ovarian tissue in adult rats, was evaluated for 28 days. The results of this study showed that following AA administration, ERK gene expression level decreased. The ERKs are members of the family of mitogen-activated protein kinases and are commonly known as cell survival factors because they regulate cell proliferation and differentiation in response to growth factors. The apoptosis induced by growth factors depletion, cellular matrix detachment, and toxic factors may be suppressed by ERK activation. However, some studies have shown that some toxic agents such as AA can induce apoptosis and eventually cell death by involving ERK pathways (Sumizawa \& Igisu 2007). The ERK pathway is associated with classic apoptosis markers such as caspase-3 and annexin V. Depending on the cell type and the nature of the injury, the ERK pathway activity can release cytochrome $c$ from the mitochondria and activate caspase-9 inhibitor or activates caspase-8. The activity of ERK pathway can also increase the level of death ligands such as Fas, FasL and TNF- $\alpha$. The ERK pathway can induce Fas activation, thereby inducing caspase- 8 activation and inducing the apoptosis process. However, it seems that ERK-mediated caspase-8 activation can occur independently from Fas activation (Cagnol \& Chambard 2010). It has been shown that the expression level of pro-apoptotic genes such as Fas and Caspase-3 can be increased in the testes of AA-treated rats, which may be related to the ERK pathway (Camacho et al. 2012; Sumizawa \& Igisu 2007). According to the results of this study, it seems that decreased ERK expression level could be related to the increased Fas expression level, thus ERK-induced apoptosis can be mediated through Fas and increase the level of apoptosis in ovarian tissue cells due to AA administration.

In the present study, AA administration reduced the number of primary, secondary graafian follicles as well as corpus luteum. The studies indicate that the toxic effects of AA on the female reproductive system decrease ovarian weight and the number of mature oocytes (Duan et al. 2015). Acrylamide can also have a negative effect on the ovarian-follicle development and corpus-luteum formation (Wei et al. 2014), which is consistent with the results of this study. Acrylamide may induce apoptosis in oocytes by increasing the reactive oxygen species and changing redox reactions. Previous studies have shown that AA induces apoptosis among oocytes by increasing Annexin V. Annexin V is a phospholipid-binding protein activates during the early stages of apoptosis (Duan et al. 2015). Following 
Table 1. Comparison the number of primary, secondary, Graaf and corpus luteum (mean \pm SD) in different groups.

\begin{tabular}{|c|c|c|c|c|}
\hline \multirow[b]{2}{*}{ Groups } & \multicolumn{4}{|c|}{ Parameters } \\
\hline & $\begin{array}{l}\text { Primary } \\
\text { Follicle }\end{array}$ & $\begin{array}{l}\text { Secondary } \\
\text { Follicle }\end{array}$ & $\begin{array}{c}\text { Graafian } \\
\text { Follicle }\end{array}$ & $\begin{array}{l}\text { Corpus } \\
\text { Luteum }\end{array}$ \\
\hline Control & $22.66 \pm 3.01$ & $7 \pm 1.67$ & $3.33 \pm 1.21$ & $11.50 \pm 1.04$ \\
\hline +VE Con & $15 \pm 1.26 *$ & $4 \pm 1.41^{*}$ & $1.83 \pm 0.4^{*}$ & $5.83 \pm 1.16^{*}$ \\
\hline -VE Con & $22.33 \pm 2.16 \dagger$ & $6.83 \pm 1.47 \dagger$ & $3.16 \pm 0.75 \dagger$ & $11 \pm 1.26^{*} \dagger$ \\
\hline Exp1 & $16.50 \pm 1.87^{*}$ & $4.50 \pm 1.37^{*}$ & $3 \pm 0.63 \dagger$ & $7.50 \pm 1.87^{*}$ \\
\hline Exp2 & $20.16 \pm 1.94 \dagger$ & $5.83 \pm 1.47 \dagger$ & $3.16 \pm 1.32 \dagger$ & $10.16 \pm 1.16 \dagger$ \\
\hline Exp3 & $21 \pm 2.19 \dagger$ & $6.50 \pm 1.87 \dagger$ & $3.33 \pm 0.51 \dagger$ & $10.33 \pm 0.51 \dagger$ \\
\hline
\end{tabular}

* Significantly different $(P<0.05)$ as compared to the control group. $\dagger$ Significantly different $(P<0.05)$ as compared to the + VE Con group

AA administration in pregnant guinea pigs, the number of healthy follicles decreased and the number of apoptotic cells increased. It appears that AA is able to break down cumulus-oocyte cellular junctions by destroying vimentin filaments and eventually induces apoptosis (Hułas-Stasiak et al. 2013). The reduction of ovarian follicles and corpus luteum may also be due to the negative effect of AA on the nitric oxide synthasedependent signaling pathway (Wei et al. 2014). Acrylamide can target and inhibit some of the cytoskeletal motor proteins such as Dynein and Kinesin. These proteins integrate cytoskeletal elements such as intermediate filaments, microfilaments, and microtubules into functional units. The inhibition of these proteins destroys the cytoskeleton, which subsequently affects cell-cell adhesion, cellular shape, intracellular communication, metabolism, synthesis and bio-chemicals' secretion (Camacho et al. 2012). Therefore, it seems that AA can disrupt the development of ovarian follicles and corpus luteum by targeting the cytoskeletal system.

$\mathrm{N}$-acetylcystein is a low-molecular-weight thiol, which is derived from the amino acid cysteine and acts as a glutathione precursor, the main antioxidant in the body and increases its amount. $\mathrm{N}$-acetylcystein plays an important role in reducing oxidative stress and eliminating reactive oxygen species and nitrogen due to its antioxidant and anti-inflammatory activities (Galhardo et al. 2007). It seems that the administration of NAC can counteract this decrease during the oxidative stresses that decrease glutathione levels and act as an antioxidant as well as an antitoxin by increasing glutathione levels. It is therefore expected that NAC will be used in a variety of diseases (Altinoz et al. 2015; Millea 2009). Glutathione plays an important role in neutralizing the pathway of toxins, including peroxide compounds and other molecules that produce free radicals and therefore has a potent protective effect on cells (Alturfan et al. 2012). NAC can also modulate pathophysiological processes such as oxidative stress, neurodegenerative processes, apoptosis and mitochondrial dysfunction (Mokhtari et al. 2017). According to the results of this study, the administration of NAC in AA-treated rats in experimental groups increased ERK gene expression in a dose-dependent manner, however, NAC administration alone in the VE Con group did not change the level of ERK gene expression. $\mathrm{N}$-acetylcystein has been shown to play an important role in chondrocyte survival by inhibiting inflammatory factors and activating ERK expression levels ( $\mathrm{Li}$ et al. 2000). The evidence also suggests that NAC may play a role in down-regulating Fas gene expression. $\mathrm{N}$-acetylcystein can reduce the sensitivity of the cells to Fas-mediated apoptosis by modulating the activity of the enzyme responsible for Fas cleavage (Delneste et al. 1996). Although the protective effects of NAC may be due to its ability as a glutathione precursor, it has been suggested that the antioxidant capacity of NAC can act independently of glutathione and play a protective role in the induced toxicity. The NAC functions in enhancing cell survival can be directly and indirectly due to its antioxidant capacity and the ability to remove free radicals (Zhang et al. 2011b).

Based on our observations, the administration of NAC in AA-treated rats in a dose-dependent manner significantly increased the number of primaries, secondary and Graafian follicles as well as corpus luteum compared to the +VE Con group, but the administration of corpus luteum alone in the -VE Con 


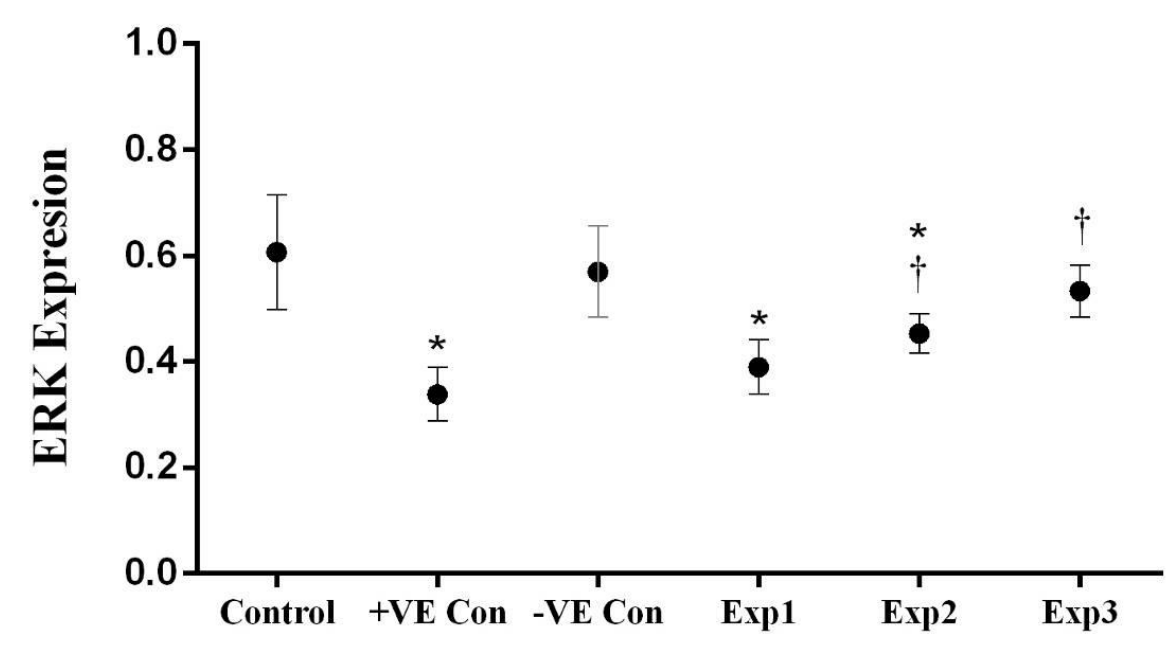

Figure 1. Comparison of ERK gene expression levels (mean $\pm \mathrm{SD})$ in different groups. * Significantly different $(P<0.05)$ as compared to the control group. $\uparrow$ Significantly different $(P<0.05)$ as compared to the $+\mathrm{VE}$ Con group.
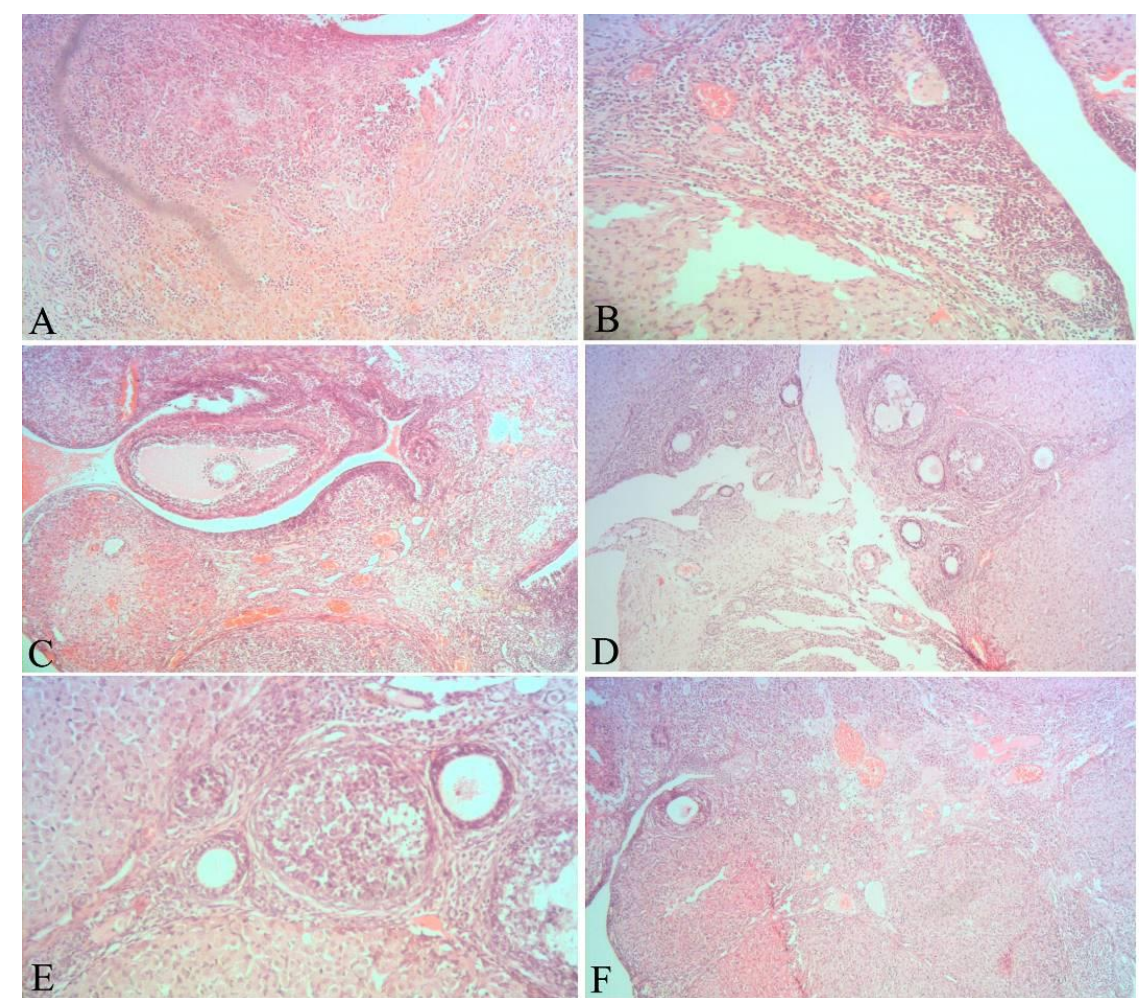

Figure 2. Photomicrograph of ovarian tissue in the rats treated with AA and NAC in different groups. A) Normal folliculogenesis was observed in the control group. B) In the +VE Con group, the reduction of ovarian follicles and corpus luteum is observed. Folliculogenesis was deteriorated. C) In the -VE Con group, the Graafian follicle is observed with a thick layer of granulosa. D) A small number of Graafian follicle and corpus luteum was observed in the experimental group 1. E and F) In the Exp2 and Exp3 groups, ovarian follicles are seen along with the corpus luteum. Folliculogenesis ameliorated. H\&E staining. A, C, D and F 4X magnification. B and E 10X magnification. 
group did not change the number of ovarian follicles and corpus luteum.

Although in our study, the administration of NAC alone did not affect on the ovarian tissue, it has been reported that during the ovarian aging process, appropriate treatment with NAC delays apoptosis and the death of healthy follicles and since oocytes and follicles can be affected by oxidative stress in the body, the ovary can be a suitable target for NAC activity (Liu et al. 2012). Nitric oxide has an important role in the development of ovarian follicles, oocyte development, ovulation, luteinization, and steroidogenesis. Nitric oxide also plays a key role in the modulation of oxidative stress and because it can directly react with Heme proteins, its excessive increase can be caused by reacting with reactive oxygen species and nitrogen, causing ovary dysfunction. Nitric oxide synthesis in the ovary is also regulated by cytokines (Hattori \& Tabata 2006). Acrylamide has been shown to increase the expression of nitric oxide (Lyn-Cook et al. 2011). Nitric oxide is synthesized by nitric oxide synthase, and AA can exert its cytotoxic effects through the nitric oxide synthase pathway on the development of ovarian follicles (Wei et al. 2014). NAC appears to modulate the toxic effects of AA on the development of ovarian follicles by affecting nitric oxide activity (Xia et al. 2006).

\section{CONCLUSION}

Acrylamide at a dose of $50 \mathrm{mg} / \mathrm{kg}$ had toxic effects on the ovarian tissue of female rats for 28 days, thereby reduced ERK gene expression and apoptosis. Acrylamide administration affects the ovarian follicles and destroys folliculogenesis. However, NAC administration in female rats treated with AA could counteract the toxic effects of AA by increasing the expression of ERK gene, reducing apoptosis and improve folliculogenesis in a dose-dependent manner. Therefore, NAC seems to be effective in reducing the negative effects of AA on the ovarian tissue of adult rats.

\section{ACKNOWLEDGEMENT}

This research is a collection of the results of the Ph.D. thesis. The authors would like to thank the Islamic Azad University of Kazerun and the Islamic Azad University of Shiraz for their cooperation in this study.

\section{REFERENCES}

Al-Shukaili A, Al-Abri S, Al-Ansari A, Monteil MA. 2009. Effect of N-acetyl-L-cysteine on Cytokine Production by Human Peripheral Blood Mononuclear Cells. Sultan Qaboos Univ Med J. 9:70-4.

Altinoz E, Turkoz Y, Vardi N. 2015. The protective effect of $\mathrm{N}$-acetylcysteine against acrylamide toxicity in liver and small and large intestine tissues. Bratislava Med J. 116:252-258.

Alturfan E, Beceren A, Şehirli A, Demiralp Z, Şener G, Omurtag G. 2012. Protective effect of N-acetyl-Lcysteine against acrylamide-induced oxidative stress in rats. Turk J Vet Anim Sci. 36:438-445.

Arranz L, Fernandez C, Rodriguez A, Rinera J, Delafuente M. 2008. The glutathione precursor N-acetylcysteine improves immune function in postmenopausal women. Free Radic Biol Med. 45:1252-1262.

Aydin Y. 2018. Acrylamide and its metabolite glycidamide can affect antioxidant defenses and steroidogenesis in Leydig and Sertoli cells. Toxicol Environ Chem. 100:247-257.

Cagnol S, Chambard J-C. 2010. ERK and cell death: Mechanisms of ERK-induced cell death - apoptosis, autophagy and senescence. FEBS J. 277:2-21.

Camacho L, Latendresse JR, Muskhelishvili L, Patton R, Bowyer JF, Thomas M, Doerge DR. 2012. Effects of acrylamide exposure on serum hormones, gene expression, cell proliferation, and histopathology in male reproductive tissues of Fischer 344 rats. Toxicol Lett. 211:135-143.

Chiew AL, Isbister GK, Duffull SB, Buckley NA. 2016. Evidence for the changing regimens of acetylcysteine. Br J Clin Pharmacol. 81:471-481.

Daneshpoya F, Karimipour M, Zirak Javanmard M, Pourheydar B. 2017. Effects of n-acetylcysteine on ovarian tissue autografted intogranulation tissue compared to back muscle in rats. TURKISH J Med Sci. 47:1931-1939.

Delneste Y, Jeannin P, Sebille E, Aubry J-P, Bonnefoy J-Y. 1996. Thiols prevent Fas (CD95)-mediated $\mathrm{T}$ cell apoptosis by down-regulating membrane Fas expression. Eur J Immunol. 26:2981-2988.

Demedts M, Behr J, Buhl R, Costabel U, Dekhuijzen R, Jansen HM, MacNee W, Thomeer M, Wallaert B, Laurent F, et al. 2005. High-Dose Acetylcysteine in Idiopathic Pulmonary Fibrosis. N Engl J Med. 353:2229-2242.

Duan X, Wang Q-C, Chen K-L, Zhu C-C, Liu J, Sun S-C. 2015. Acrylamide toxic effects on mouse oocyte quality and fertility in vivo. Sci Rep. 5:11562.

Galhardo MA, Júnior CQ, Navarro PGR, Morello RJ, De Jesus Simões M, De Souza Montero EF. 2007. Liver and lung late alterations following hepatic reperfusion associated to ischemic preconditioning orNacetylcysteine. Microsurgery. 27:295-299.

Hattori M, Tabata S. 2006. Nitric oxide and ovarian function. Anim Sci J. 77:275-284. 
Hułas-Stasiak M, Dobrowolski P, Tomaszewska E, Kostro K. 2013. Maternal acrylamide treatment reduces ovarian follicle number in newborn guinea pig offspring. Reprod Toxicol. 42:125-131.

Kahkeshani N, Saeidnia S, Abdollahi M. 2014. Role of antioxidants and phytochemicals on acrylamide mitigation from food and reducing its toxicity. J Food Sci Technol. 52:3169-3186.

Klaunig JE. 2008. Acrylamide Carcinogenicity. J Agric Food Chem. 56:5984-5988.

Li WQ, Dehnade F, Zafarullah M. 2000. Thiol Antioxidant, N-Acetylcysteine, Activates Extracellular SignalRegulated Kinase Signaling Pathway in Articular Chondrocytes. Biochem Biophys Res Commun. 275:789-794.

Liu J, Liu M, Ye X, Liu K, Huang J, Wang L, Ji G, Liu N, Tang X, Baltz JM, et al. 2012. Delay in oocyte aging in mice by the antioxidant N-acetyl-l-cysteine (NAC). Hum Reprod. 27:1411-1420.

Lyn-Cook LE, Tareke E, Word B, Starlard-Davenport A, LynCook BD, Hammons GJ. 2011. Food contaminant acrylamide increases expression of Cox-2 and nitric oxide synthase in breast epithelial cells. Toxicol Ind Health. 27:11-18.

Marcondes FK, Bianchi FJ, Tanno AP. 2002. Determination of the estrous cycle phases of rats: some helpful considerations. Brazilian J Biol. 62:609-614.

Markoutsa E, Xu P. 2017. Redox Potential-Sensitive N Acetyl Cysteine-Prodrug Nanoparticles Inhibit the Activation of Microglia and Improve Neuronal Survival. Mol Pharm. 14:1591-1600.

Millea PJ. 2009. N-acetylcysteine: multiple clinical applications. Am Fam Physician. 80:265-9.
Mokhtari V, Afsharian P, Shahhoseini M, Kalantar SM, Moin A. 2017. A Review on Various Uses of N-Acetyl Cysteine. Cell J. 19:11-17.

Proietti I, Frazzoli C, Mantovani A. 2014. Identification and management of toxicological hazards of street foods in developing countries. Food Chem Toxicol. 63:143-152.

Saha L, Saha P, Kaur S. 2013. N -acetyl cysteine in clomiphene citrate resistant polycystic ovary syndrome: A review of reported outcomes. J Pharmacol Pharmacother. 4:185.

Sumizawa T, Igisu H. 2007. Apoptosis induced by acrylamide in SH-SY5Y cells. Arch Toxicol. 81:279-282.

Wang J, Chen S, Gao Y, Qiao L, Zhang J, Liu J. 2015. Effect of Repeated Electroacupuncture Intervention on Hippocampal ERK and p38MAPK Signaling in Neuropathic Pain Rats. Evidence-Based Complement Altern Med. 2015:1-10.

Wei Q, Li J, Li X, Zhang L, Shi F. 2014. Reproductive toxicity in acrylamide-treated female mice. Reprod Toxicol. 46:121-128.

Xia Z, Nagareddy PR, Guo Z, Zhang W, Mcneill JH. 2006. Antioxidant $\mathrm{N}$-acetylcysteine restores systemic nitric oxide availability and corrects depressions in arterial blood pressure and heart rate in diabetic rats. Free Radic Res. 40:175-184.

Zhang F, Lau SS, Monks TJ. 2011a. The Cytoprotective Effect of N-acetyl-L-cysteine against ROS-Induced Cytotoxicity Is Independent of Its Ability to Enhance Glutathione Synthesis. Toxicol Sci. 120:87-97.

Zhang L, Gavin T, Barber DS, LoPachin RM. 2011b. Role of the Nrf2-ARE pathway in acrylamide neurotoxicity. Toxicol Lett. 205:1-7. 